\title{
The investigation of the effect of freezing pretreatment on properties of black garlic produced from Kastamonu garlic
}

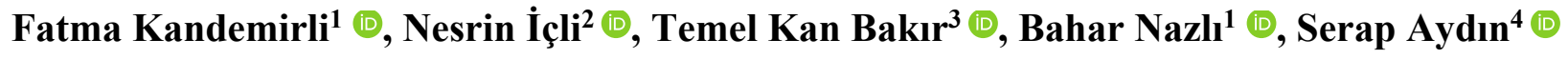 \\ Cite this article as: \\ Kandemirli, F., İçli, N., Bakır, T.K., Nazlı, B., Aydın, S. (2020). The investigation of the effect of freezing preatreatment on properties of black garlic \\ produced from Kastamonu garlic. Food and Health, 6(1), 1-8. https://doi.org/10.3153/FH20001
}

\footnotetext{
Kastamonu University, Faculty of Engineering and Architecture, Biomedical Engineering Department, Kastamonu, Turkey

${ }^{2}$ Kastamonu University, Department of Nutrition and Dietetics, Kastamonu, Turkey

${ }^{3}$ Kastamonu University, Faculty of Science, Art and Architecture, Chemistry Department, Kastamonu, Turkey

${ }^{4}$ Kastamonu University, Faculty of Engineering and Architecture, Food Engineering Department, Kastamonu, Turkey
}

ORCID IDs of the authors:

F.K. 0000-0001- 6097-2184

N.İ. 0000-0002-0617-0639

T.K.B. 0000-0002-7447-1468

B.N. 0000-0001-8841-8636

S.A. 0000-0002-4348-7088

Submitted: 17.05 .2019

Revision requested: 03.06.2019

Last revision received: 18.06 .2019

Accepted: 01.07.2019

Published online: 06.11.2019

Correspondence:

Bahar NAZLI

E-mail: btastan@kastamonu.edu.tr

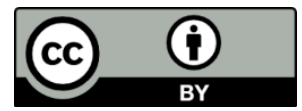

(C)Copyright 2020 by ScientificWebJournals Available online at

http://jfhs.scientificwebjournals.com

\begin{abstract}
Black garlic is obtained by fermentation of fresh garlic in condition under controlled high humidity and temperature. The aim of this study is to investigate the effect of freezing as pre-treatment process on black garlic produced from fresh Kastamonu garlics in terms of various antioxidant activity parameters, phenolic and flavanoid contents, fermentation time and HMF formation. The antioxidant properties analysis results of frozen and non-frozen black garlic samples were shown that higher than those of white garlic and it was observed that total antioxidant capacity, the total phenolic compound and total flavanaoid content values of black garlics increase with the storage period under fermentation conditions. In addition, frozen garlics were found to have higher total antioxidant activities on the 25th and 30th days $(9.56 \mathrm{mg} \mathrm{AE} / \mathrm{g}$ and $10.40 \mathrm{mg} \mathrm{AE} / \mathrm{g}$, respectively) of the fermentation than the activities of non-frozen garlics the on the 35 th day $(8.49 \mathrm{mg} \mathrm{AE} / \mathrm{g})$ of fermentation. The toxic compound HMF formation was found of the frozen sample at as high as $110 \mathrm{mg} / \mathrm{kg}$ in end of the 35th day. In conclusion, the use of pre-frozen garlics in black garlic production will be more efficient in respect of antioxidant properties and time and cost saving.
\end{abstract}

Keywords: Black garlic, Kastamonu garlic, Antioxidant activity, HMF 


\section{Introduction}

Nowadays, people have interest in foods with strong natural antioxidants and polyphenolic contents in order to maintain a healthy and balanced diet. Especially the use of natural products in the treatment of diseases increased the clinical trials of these products. (Ercişli, S. 2008). It has been reported that garlic reduces the risk of breast cancer, the risk of brain haemorrhage and the risk of heart attack and slows down the progression of these diseases (De La Cruz and Garzía, 2007). Garlic (Allium sativum) is widely used in the world and is known as a spice with important polyphenolic contents. In addition, the anti-bacterial property of garlic has been known for many years (Marchese et al., 2016). It is believed that the medical and beneficial properties can be attributed to certain components present in garlic and extracts, and many studies are associated with organosulfur compounds. (Tumors et al., 2006).

There are studies showing the changes in phenol content and antioxidant capacity according to the processing and storage life changes of garlic containing products (Queiroz et al. 2009). Black garlic, a garlic product, has been widely used in health and cosmetics in recent years. Black garlic is obtained by keeping fresh garlic under controlled temperature and humidity for a while. The processing time varies between 5-45 days depending on the temperature. It is kept in the temperature range $60^{\circ} \mathrm{C}$ to $90^{\circ} \mathrm{C}$ during the process and under controlled humidity with no additional treatment and additives (Toledano et al. 2016). When the garlic is cut or crushed, the allicin which produces a sharp smell of garlic occurs (Marchese et al., 2016). This sharp flavor and the smell of fresh garlic limits the use of garlic. Black garlic does not have this pungent odor and some bioactive properties such as increased antioxidant properties vary. ( $\mathrm{Li}$ et al., 2015). 5-Hydroxymethylfurfural (HMF) content, allicin content, amino acid, nitrogen compounds, total acid content and total phenol content were determined by Zhang et al. The results of HMF analysis and total phenolics showed that a significant difference was observed in the samples that had darkened at different temperature values (Zhang, et al., 2016). Kimura et al. investigated the production, bioactivity and applications of black garlic (2017). When compared to the biological activity of black garlic and fresh garlic, black garlic is said to have advantages such as antiallergic, antioxidant and anti-cancer properties (Kimura et al., 2017). It was stated that the use of black garlic had no adverse effect on the medical field or the food industry and that the biological activity of black garlic could be increased by fermentation using yeast (Jung et al., 2011). Exposing the garlic to high temperatures in the blackening process will destroy the cell wall. The process of freezing the cell wall by pretreating the garlic before exposure to high temperatures influences the darkening process. The samples exposed to freezing were observed to darken approximately twice as fast. It was shown that the study reduced the blackening time and TPC, HMF-5 affect the sugar content change and amino-N content (Li et al., 2015).

The aim of this study is to investigate the effect of freezing pre-treatment before black garlic production process on antioxidant properties of black garlics such as DPPH radical scavenging activities, total phenolic content, total antioxidant capacity, total flavanoid content and ferric reducing antioxidant power (FRAP) and is observe to toxic HMF formation levels of frozen and non-frozen garlics on fermentation process time. Hence, the fermentation process was applied to frozen and non-frozen Kastamonu Garlic, an endemic plant, under optimum conditions compiled from the literature given above, for the production of black garlic. It was also investigated whether the pre-freezing treatment reduce or not the fermentation process time. This study is the first study about Kastamonu garlic on this subject and there is no study to investigate how the freezing process changes on various antioxidant activities during production of black garlic, in the literature review.

\section{Materials and Methods}

All analytical grade chemicals were purchased from SigmaAldrich Co. LLC. Deionized water was used to prepare all aqueous solutions. Absorbances were measured using a pair of identical quartet baths of $1 \mathrm{~cm}$ thickness using a SHIMADZU UVM-1240 UV-Visible spectrophotometer (manufactured by Shimazu Corp., Kyoto, Japan). The SHIMADZU LC20-A Prominence high performance liquid chromatography (HPLC) device (manufactured by Shimazu Corp., Kyoto, Japan) was used for HMF analysis.

\section{Preparation Procedure of Black Garlic}

In order to look at the effect of the freezing process on the blackening process, 16 garlic bulb were frozen at $-16{ }^{\circ} \mathrm{C}$ for 30 hours. After freezing, the frozen and non-frozen garlic were placed in a $60{ }^{\circ} \mathrm{C}$ special oven and under optimum conditions compiled from the literature for the blackening. One sample was taken on the 20th, 25th, 30th and 35th days of frozen and non-frozen garlic. All samples were stored at -16 ${ }^{\circ} \mathrm{C}$ for use in experiments.

\section{Preparation of Black Garlic Extracts}

Garlic extracts were prepared according to a standard protocol with minor modifications. 2.0 grams of garlic was taken from the garlic and crushed in porcelain mortar. It was then solved in $20 \mathrm{~mL}$ of a distilled water solution. After standing 
at $4{ }^{\circ} \mathrm{C}$ for 24 hours, the mixture was filtered through filter paper. The resulting homogenate was centrifuged at 5000 $\mathrm{rpm}$ for 10 minutes $\left(18^{\circ} \mathrm{C}\right)$. The last supernatant was removed $(100 \mathrm{mg} / \mathrm{mL})$. It was used for the measurement of all analysis parameters investigated in this study (Pedraza-Chaverri et al., 2004).

\section{DPPH Radical Scavenging Assay}

In this study, antioxidant activity of frozen and non-frozen garlic samples were investigated by DPPH (1,1-diphenyl-2picryl hydrazyl) radical scavenging method at different storage times. The effect of ethanolic extracts of the garlic samples on the DPPH radical was monitored with a spectrophotometer at $517 \mathrm{~nm}$. DPPH solution at concentration of $1.35 \times 10^{-4} \mathrm{M}$ was used as control solution. The absorbance change in the solution was measured at four different concentrations for each added garlic extract at $0.166-0.666 \mathrm{mg} / \mathrm{mL}$. In addition, DPPH calibration solutions were prepared at $4.10^{-6} \mathrm{M}-2.10^{-4} \mathrm{M}$ concentrations by diluting the stock $\left(4 \times 10^{-}\right.$ $\left.{ }^{4} \mathrm{M}\right) \mathrm{DPPH}$ solution. Calibration equation was found as $\mathrm{y}=$ $(8.7 \pm 0.22)^{\times} 10^{3} \mathrm{x}+0.085$. Thus, the percent radical scavenging activity was calculated by the following formula:

$\%$ inhibition $=\left[\left(\mathrm{C}_{0}-\mathrm{C}_{1}\right) / \mathrm{C}_{0}\right] \times 100$ (Bakir et al., 2018).

where $\mathrm{C}_{0}$ is the absorbance in the presence of control absorbance and $\mathrm{C}_{1}$ samples. Consequently, IC50 values of inhibition change depending on concentration of garlic samples were obtained as suggested by Mukherjee et al., (2011).

\section{Determination of Total Phenolics}

The total phenolic component of the ethanol extracts of garlic samples was determined using the Folin-Ciocalteu reagent in the literature (Slinkard and Singleton, 1977) and the gallic acid-containing method as standard. For the application of this method, $4.5 \mathrm{~mL}$ of deionized water and $0.1 \mathrm{~mL}$ of FolinCiocalteu reagent were added. After 3 minutes, $0.3 \mathrm{~mL}$ $\mathrm{Na}_{2} \mathrm{CO}_{3}(2 \%)$ solution and 0.1 extract solution were added and vigorously shaken. After a 2 hour waiting period, the absorption was measured at $760 \mathrm{~nm}$. The concentrations of the phenolic compounds were calculated according to the following equation, obtained from the standard gallic acid (GA) graph:

Absorption $=0.537 \mathrm{GA}(\mu \mathrm{M})+0.03, \mathrm{R}^{2}=0.999$

\section{Total Antioxidant Capacity Analysis}

Reduction of Mo (VI) to Mo (V) and formation of green colored phosphate / Mo (V) complex in acidic environment are the basis of the method. $500 \mathrm{mg} / \mathrm{L}$ ascorbic acid standard stock solution was prepared and diluted to 5 different concentrations $\left(y=0.0033 x-0.0601\right.$ and $\left.R^{2}=0.996\right)$. Then $28 \mathrm{mM}$
$\mathrm{Na}_{2} \mathrm{HPO}_{4} .12 \mathrm{H}_{2} \mathrm{O}$ solution, $0.6 \mathrm{M} \mathrm{H}_{2} \mathrm{SO}_{4}$ solution, $4 \mathrm{mM}$ ammonium molybdate solutions were prepared and $25 \mathrm{~mL}$ of them were mixed and used as the reagent solution. $0.3 \mathrm{~mL}$ of garlic extract was taken into a tube and $3 \mathrm{~mL}$ of the reagent solution was added. The tubes were mixed well and kept at $95{ }^{\circ} \mathrm{C}$ for 90 minutes. The absorbance of the solutions was then measured at $695 \mathrm{~nm}$. All these procedures were performed for ascorbic acid which is used as standard antioxidant. Antioxidant activity was calculated as ascorbic acid equivalent (mg AE/g garlic or black garlic) (Prieto, Pineda, \& Aguilar, 1999).

\section{HMF Analysis}

The samples were thoroughly ground and homogenized. Weigh $2.5 \mathrm{~g}$ of sample into $50 \mathrm{~mL}$ flasks. The samples weighed $50 \mathrm{~mL}$ with ultrapure water. After shaking, dissolution in ultrasonic bath for $30 \mathrm{sec}$ was achieved. Filtered through coarse filter. The filtrate was filtered through the 25 $\mu \mathrm{m}$ microfilter and collected in the vial. Analysis was carried out by HPLC belonging to Kastamonu University Central Research Laboratory Application and Research Center. Results were calculated to be mg HMF in kg garlic or black garlic. The HPLC condutions were applied according to the method of Kalábová and Večerek, (2006).

\section{Total Flavanoid Analysis}

Quercetin stock solution was prepared at a concentration of $200 \mathrm{mg} / \mathrm{L}$ and five different concentrations were obtained by dilution from this concentration $\left(\mathrm{y}=0.0349 \mathrm{x}+0.0295\right.$ and $\mathrm{R}^{2}$ $=1)$. Black garlic extracts $(1 \mathrm{~mL})$ were mixed with $2 \% \mathrm{AlCl}_{3}$ in the same amount for 10 minutes under room conditions. The absorbances of the samples at $415 \mathrm{~nm}$ were recorded. The same procedures were also performed for the standard quercetin and the flavanaoid contents of the samples were calculated as the equivalent of Quercetin (mg QE g garlic or black garlic) (Arvouet-Grand, Vennat, Pourrat, \& Legret, 1994).

\section{Ferric Reducing Antioxidant Power (FRAP) Analysis}

Dilution of the extracts was done with some modifications according to Benzie and Strain. Stock solutions contained a solution of $300 \mathrm{mM}$ acetate buffer $\left(3.1 \mathrm{~g}\right.$ of $\mathrm{C}_{2} \mathrm{H}_{3} \mathrm{NaO}_{2}-3 \mathrm{H}_{2} \mathrm{O}$ and $16 \mathrm{~mL}$ of $\left.\mathrm{C}_{2} \mathrm{H}_{4} \mathrm{O}_{2}\right)$, pH 3.6, $10 \mathrm{mM}$ TPTZ $(2,4,6$-trisyridyls-triazine) in $40 \mathrm{mM} \mathrm{HCl}$ and $20 \mathrm{mM} \mathrm{FeSO}_{4}$. The fresh working solution was prepared by mixing 1: 1: $10 \mathrm{TPTZ}$ solution, $\mathrm{FeSO}_{4} .7 \mathrm{H}_{2} \mathrm{O}$ solution and acetate buffer and heated at $37{ }^{\circ} \mathrm{C}$ for 25 minutes before use. Plant extract or reference was allowed to react with FRAP solution in dark conditions for 30 min. Measurements of the colored product (iron tripliridridiazine complex) were then performed at $593 \mathrm{~nm}$. Results were expressed as $\mathrm{mM} \mathrm{FeSO} 4.7 \mathrm{H}_{2} \mathrm{O}$ equivalent in $\mathrm{mg}$ garlic or 
black garlic. The equation and correlation coefficient of the calibration graph were as $\mathrm{y}=1.9558 \mathrm{x}-0.0024$ and $\mathrm{R}^{2}=0.999$, respectively.

\section{Results and Discussion}

\section{The Evaluation of Odour, Taste and Colour}

Blacking changes in different fermentation days of has been observed garlic by Reis Tarim Urunleri San Tic. A.S. Black garlic samples were observed at the 20th, 25th, 30th and 35th days. The pre-frozen and non-frozen samples were compared at 20th day and that it was found that pre-frozen garlic was darker and drier and the odour of pre-frozen and non-frozen samples was disturbingly sharp. When the 25th day samples were examined, it was determined that the taste bitter and water decreased. In the 30th day samples, it was found that the color of the frozen samples was darker and these samples have more hard structure and the better taste compared to the non-frozen samples. When the samples were examined on the 35 th day, it was observed that the frozen samples were black, bitter and dry; the non-frozen samples were black, bitter and hard.

\section{The Evaluation of DPPH Radical Scavenging Activities, Total Phenolic Compound, Total Antioxidant Capacity, Total Flavanoid Content and FRAP Analysis}

The DPPH radical scavenging activities, total phenolic content, total antioxidant capacity, total flavanaoid and FRAP analysis of frozen and non-frozen black garlic species were evaluated at different storage times in this study. The results are presented in Table 1. All of the results of analysis indicated antioxidant properties of black garlic were found that higher than those of white garlic. Similarly, black garlic has proven its benefits to human health, due to its high content of antioxidants and phenolic substances compared to fresh garlic (Akan, 2014). Purev et al. (2012) showed that black garlic and fresh garlic were directly related to anti-carcinogenic and antioxidant activity in their study on immune system cells. Kim et. al., (2012) studied the change in total phenolic and flavanoid content of black garlic produced in different moisture, temperature and storage media. Studies have shown that garlic is a plant with antitumor and antioxidant properties besides regulating blood pressure, lowering cholesterol, bacterial infections and strengthening the immune system (Ayaz and Alpsoy 2007). The inhibition (\%) values in the concentration range of $0.33-2.66 \mathrm{mg} / \mathrm{mL}$ as compared to the storage times for black garlic samples were shown in Figure 1.

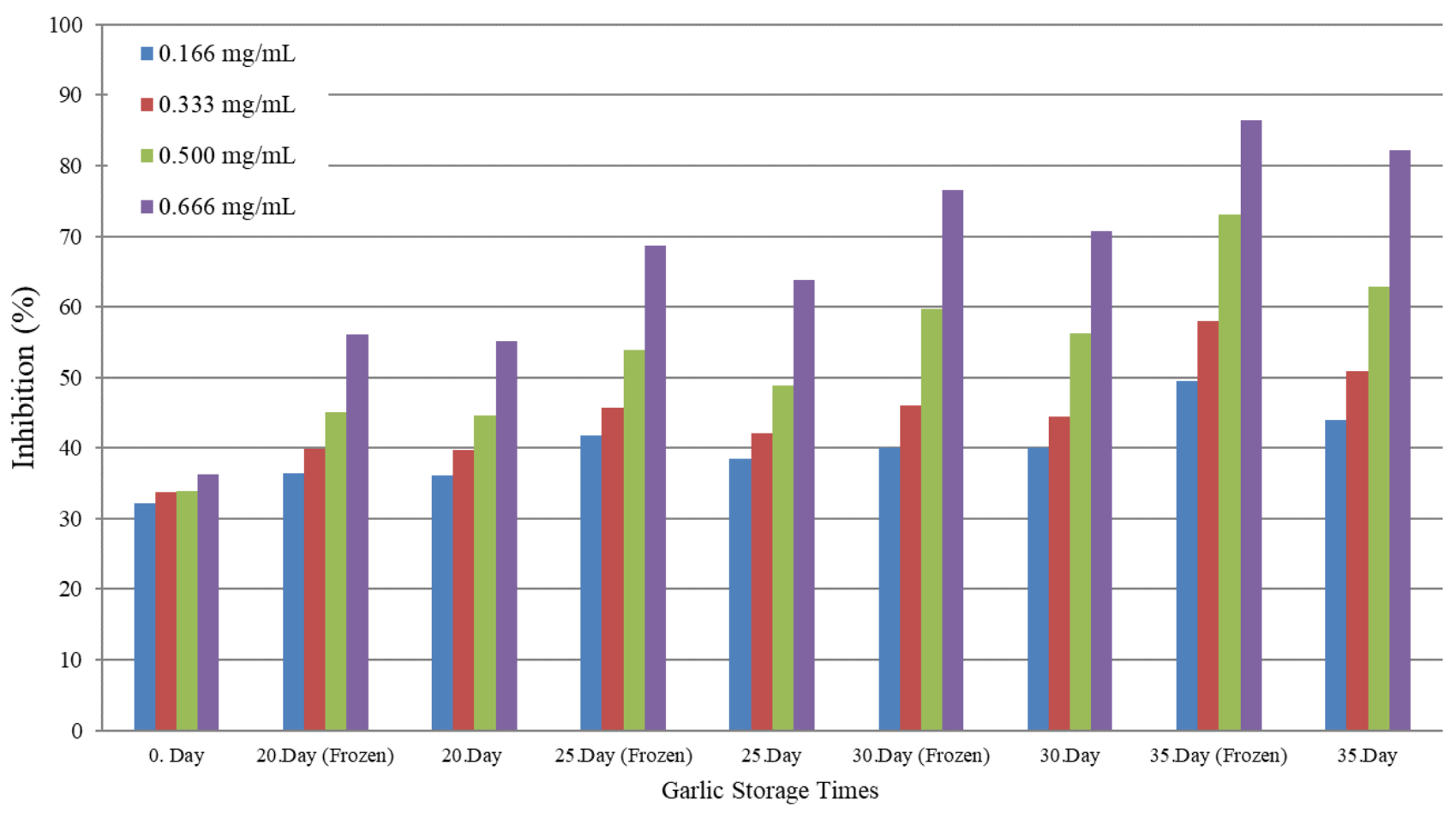

Figure 1. Free radical scavenging capacities (measured by the DPPH test) of different concentrations of frozen and non-frozen black garlic extract kept at different storage times. 
The \% inhibition values obtained DPPH analysis of all garlic samples were changed in proportion to the increase in concentration. Similarly, when different storage periods were taken into consideration, the inhibition values increased with storage times. Frozen samples were found to have higher inhibition at all concentrations compared to non-frozen black garlic samples. Accordingly, frozen black garlic has been shown to increase the phenolic and flavanaoid contents in optimum conditions compared to non-frozen black garlic. The IC50 values were inversely proportional to the storage time in both frozen and non-frozen black garlic samples. Thus, free radical scavenging capacity was found to increase with storage times. Similarly, it is seen that total antioxidant capacity, the total phenolic compound and total flavanaoid content values increase with the storage period (Table 1). However, it is seen that frozen samples contain higher phenolic compound and total flavanaoid content than non-frozen samples in all storage periods at fermentation conditions. Although, the FRAP value of frozen and non-frozen black garlic was higher than the value of white garlic, theirs values are the same each other. Moreover, the FRAP value of frozen and non-frozen black garlic was almost never increased with storage time. So when these results are evaluated for black garlic samples, the reasons of high antioxidant capacity and good health effects is thought to be related to high free radical scavenging activity, total phenolic and flavanaoid content. Similarly, Sato et al. (2006) explained that the shorter time fermented black garlic $\left(60-70{ }^{\circ} \mathrm{C}, 85-90 \%\right.$ relative humidity 40 days) increased the phenolic content 13 -fold compared to fresh garlic and the antioxidative properties became more effective. In addition, frozen garlics were found to have higher total antioxidant activities at the 25th and 30th days of the fermentation than the activities of non-frozen garlics the at the 35th day of fermentation. Hence, the frozen process also accelerates the fermentation process similar to study of Li et al. (2015) and thus enhances the formation of antioxidant compounds.

\section{The Evaluation of HMF Formation}

The HMF causing irritation to upper respiratory tract, eyes, skin and mucous membranes, and is cytotoxic at high concentrations. In addition, also determined an oral LD50 to be $3.1 \mathrm{~g} / \mathrm{kg}$ body weight for rats (Ulbricht, et al., 1984; Matic, et al., 2009). Carcinogenic potential of HMF has been researched in investigation on rodents. HMF has been demonstrated to promote and induce preneoplastic lesions as aberrant crypt foci (ACP) in rat colon (Archer et al.,1992; Bruce et al.,1993; Zhang et al., 1993) Recently, HMF has been shown that a weak carcinogen in multiple intestinal neoplasia $(\mathrm{min} / \mathrm{b})$ mice and significantly increasing the number of small intestine adenomas (Svendsen, Husøy, Glatt, Paulsen, \& Alexander, 2009). Lastly, HMF has been reported that produces mutagenic effects by transforming into 5-sulfoxymethylfurfural (SMF), a highly reactive intermediate that can react with DNA and other macromolecules. (Bakhiya et al., 2009; Córdovaa et al., 2019).

Table 1. The Result of Total Phenolic, DPPH IC50, Total Antioxidant Capacity, Total Flavanoid, FRAP and HMF Analysis at different storage times under fermentation conditions for frozen and non-frozen black garlic samples.

\begin{tabular}{|c|c|c|c|c|c|c|c|c|c|}
\hline & \multicolumn{5}{|c|}{ Storage Times of Garlic Samples (Day) } & \\
\hline & \multirow{2}{*}{$\begin{array}{l}\text { Fresh } \\
\text { 0 }\end{array}$} & \multicolumn{4}{|c|}{ non-frozen } & & & & frozen \\
\hline & & 20 & 25 & 30 & 35 & 20 & 25 & 30 & 35 \\
\hline $\begin{array}{l}\text { Total Phenolic } \\
\text { (mg GA/g) }\end{array}$ & 2.68 & 84.61 & 69.72 & 170.28 & 278.29 & 86.48 & 140.48 & 181.45 & 378.85 \\
\hline $\begin{array}{l}\text { DPPH IC }_{50} \\
(\mathrm{mg} / \mathrm{mL})\end{array}$ & 2.58 & 0.58 & 0.45 & 0.37 & 0.29 & 0.56 & 0.37 & 0.34 & 0.19 \\
\hline $\begin{array}{l}\text { Total Antioxidant } \\
\text { Capacity Analysis } \\
\text { (mg AE/g) }\end{array}$ & 6.21 & 6.45 & 7.26 & 7.94 & 8.49 & 8.33 & 9.56 & 10.40 & 10.85 \\
\hline $\begin{array}{l}\text { Total Flavanoid } \\
(\mathrm{mg} Q \mathrm{QE} / \mathrm{g})\end{array}$ & 0.26 & 0.31 & 0.34 & 0.36 & 0.59 & 0.38 & 0.45 & 0.62 & 0.85 \\
\hline $\begin{array}{lr}\text { FRAP } & \text { Analysis } \\
\left(\mathrm{mMFeSO}_{4 .} .7 \mathrm{H}_{2} \mathrm{O} / \mathrm{g}\right)\end{array}$ & 0.09 & 0.23 & 0.23 & 0.23 & 0.24 & 0.23 & 0.24 & 0.24 & 0.24 \\
\hline $\begin{array}{l}\text { HMF } \\
(\mathrm{mg} / \mathrm{kg})\end{array}$ & 0.18 & 2.00 & 6.40 & 19.80 & 34.00 & 3.20 & 9.80 & 27.60 & 110.00 \\
\hline
\end{tabular}


The HMF analysis results show that a very high and risky HMF formation on the 35th day in the frozen sample at 110 $\mathrm{mg} / \mathrm{kg}$, and show that a very low HMF level at $9.80 \mathrm{mg} / \mathrm{kg}$ on the 25th day. Even on the 30th day, the frozen black garlic has a relatively low HMF level $(34.00 \mathrm{mg} / \mathrm{kg})$, the level of HMF of the black garlic produced without freezing was lower on the 35 th day $(27.60 \mathrm{mg} / \mathrm{kg})$. However, since the fermentation time of black garlics produced from frozen garlics is almost completed at the range of 25-30th days of fermentation according to data obtained from our study, it is clear that the consumption pre-frozen black garlic does not pose any risk for HMF toxicity at 25th and 30th days of fermentation.

\section{Conclusion}

In the production of black garlic, it is seen that pre-freezing before fermentation will shorten the production process and thus the costs will decrease. It has been found that the use of frozen samples results in an increase in total phenolic substances and antioxidant capacity in black garlic contents compared to non-frozen products. It has also been found that the formation of HMF which has toxic properties occurs in low amounts at the 25 th and 30th day as the process completion time of the fermentation of frozen samples. Hence, no present any danger in terms of health hazards of HMF occurred in frozen black garlic at 30th day fermentation. The results of this study show that the use of frozen garlics in black garlic production will be more efficient in respect of antioxidant properties and time and cost saving.

\section{Compliance with Ethical Standard}

Conflict of interests: The authors declare that for this article they have no actual, potential or perceived the conflict of interests.

Financial disclosure: This study was supported by Kastamonu University Scientific Research Coordination Unit. Project Number KÜ-BAP06/2017-1.

Ethics committee approval: No ethics committee approval is needed.

Acknowledgement: We thank the Kastamonu University Scientific Research Studies Project Management Coordination. The authors are also grateful to Kastamonu University Central Research Laboratory Application and Research Center. Special thanks for Reis Gida Company supplied to material.

\section{References}

Akan, S. (2014). Siyah sarımsak, Gida, 39(6), 363-370, https://doi.org/10.15237/gida.GD14018

Ayaz, E., Alpsoy, H.C. (2007). Sarımsak (Allium sativum L.) ve geleneksel tedavide kullanımı. Türkiye Parazitoloji Dergisi, 31(2), 145-149.

Archer, M.C., Bruce, W.R., Chan, C.C., Corpet, D.E., Medline, A., Roncucci, L., Zhang, X.M. (1992). Aberrant crypt foci and microadenoma as markers for colon cancer. Environmental Health Perspectives, 98, 195-197. https://doi.org/10.1289/ehp.9298195

Arvouet-Grand, A., Vennat, B., Pourrat, A., Legret, P. (1994). Standardisation d' un extrait de propolis et identification desprincipaux constituants. Journal de Pharmacie de Belgique, 49, 462-468.

Bakhiya, N., Monien, B., Frank, H., Seidel, A., Glatt G. (2009). Renal organic anion transporters OAT1 and OAT3 mediate the cellular accumulation of 5-sulfooxymethylfurfural, a reactive, nephrotoxic metabolite of the Maillard product 5-hydroxymethylfurfural. Biochemical Pharmacology, 78, 414-419.

https://doi.org/10.1016/j.bcp.2009.04.017

Bakir, T., Karadeniz, M., Unal, S. (2018). Investigation of antioxidant activities of Pleurotus ostreatus stored at different temperatures, Food Science \& Nutrition, 6(4), 1040-1044. https://doi.org/10.1002/fsn3.644

Benzie, I.F.F., Strain J.J. (1996). The Ferric Reducing Ability of Plasma (FRAP) as a measure of 'antioxidant power': the FRAP assay. Analytical Biochemistry, 239, 70-76. https://doi.org/10.1006/abio.1996.0292

Bruce, W.R., Archer, M.C., Corpet, D.E., Medline, A., Minkin, S., Stamp, D., Ying, Y., Zhang, X.M. (1993). Diet, aberrant crypt foci and colorectal cancer. Mutation Research, 290, 111-118.

https://doi.org/10.1016/0027-5107(93)90038-H

Córdova, A., Saavedra, J., Mondaca, V., Vidal, J., Astudillo-Castro C. (2019). Quality assessment and multivariate calibration of 5-hydroxymethylfurfural during a concentration process for clarified apple juice. Food control, 95, 106-114.

https://doi.org/10.1016/j.foodcont.2018.07.050 
De La Cruz, J., García, H.S. (2007). Garlic: Post- Harvest Operatio. Agricultural and Food Engineering Technologies Service, 2-40. Retrieved from http://www.fao.org/fileadmin/user upload/inpho/docs/Post Harvest Compendium -

Garlic.pdf (accsessed 21.12.2007)

Ercisli, S., Akbulut, M., Ozdemir, O., Sengul, M., Orhan, E. (2008). Phenolic and antioxidant diversity among persimmon (Diospyrus kaki L.) genotypes in Turkey. International Journal of Food Sciences and Nutrition, 59(6), 477-482. https://doi.org/10.1080/09637480701538262

Jung, Y.M., Lee, S.H., Lee, D.S., You, M.J., Chung, I.K., Cheon, W.H., Kwon, Y.S., Lee, Y.J., Ku, S.K. (2011). Fermented garlic protects diabetic, obese mice when fed a highfat diet by antioxidant effects. Nutrition Research, 31(5), 387-396.

https://doi.org/10.1016/j.nutres.2011.04.005

Kalábová, L.V.I.B.K., Večerek, V. (2006). Hydroxymethylfurfural contents in foodstuffs determined by HPLC method. Journal of Food and Nutrition Research, 45(1), 34-38.

Kim J-S, Kanga O-J, Gweonb 0-C. (2013). Comparison of phenolic acids and flavanaoids in black garlic at different thermal processing steps. Journal of Functional Foods, 5(1), 80-86.

https://doi.org/10.1016/j.jff.2012.08.006

Kimura, S., Tung, Y.C., Pan, M.H., Su, N.W., Lai, Y.J., Cheng, K.C. (2017). Black garlic: A critical review of its production, bioactivity, and application. Journal of Food and Drug Analysis, 25(1), 62-70.

https://doi.org/10.1016/j.jfda.2016.11.003

Li, N., Lu, X., Pei, H., Qiao, X. (2015). Effect of freezing pretreatment on the processing time and quality of black garlic. Journal of Food Process Engineering, 38(4), 329-335. https://doi.org/10.1111/jfpe.12156

Marchese, A., Barbieri, R., Sanches-Silva, A., Daglia, M., Nabavi, S. F., Jafari, N. J., Izadi, M., Ajami, M., Nabavi, S. M. (2016). Antifungal and antibacterial activities of allicin: A review. Trends in Food Science and Technology, 52, 49-56.

https://doi.org/10.1016/j.tifs.2016.03.010

Matić, J.J., Šarić, B.M., Mandić, A.I., Milovanović, I.L., Jovanov, PT., Mastilović J.S. (2009). Determination of 5Hydroxymethylfurfural in apple juice. Food and Feed Research, 36(1-2), 35-40.
Mukherjee, S., Pawar, N., Kulkarni, O., Nagarkar, B., Thopte, S., Bhujbal, A., Pawar, P. (2011). Evaluation of free-radical quenching properties of standard Ayurvedic formulation Vayasthapana Rasayana. BMC Complementary and Alternative Medicine, 11(38), 1-6.

https://doi.org/10.1186/1472-6882-11-38

Pedraza-Chaverri, J., Gil-Ortiz, M., Albarran, G., Barbachano-Esparza, L., Menjıvar, M., Medina-Campos, O.N. (2004). Garlic's ability to prevent in vitro $\mathrm{Cu} 2+$-induced lipoprotein oxidation in human serum is preserved in heated garlic: effect unrelated to $\mathrm{Cu} 2+-$-chelation. Nutrition Journal, 3,10 .

https://doi.org/10.1186/1475-2891-3-10

Prieto, P., Pineda, M., Aguilar, M. (1999). Spectrophotometric quantitation of antioxidant capacity through the formation of a phosphor molybdenum complex: Specific application to the determination of vitamin E. Analytical Biochemistry, 269, 337-341.

https://doi.org/10.1006/abio.1999.4019

Purev, U., Chung, M., Oh, D.-H. (2012). Individual differences on immunostimulatory activity of raw and black garlic extract in human primary immune cells. Immunopharmacology and Immunotoxicology, 34(4), 651-660.

https://doi.org/10.3109/08923973.2011.649288

Queiroz, Y.S., Ishimoto, E. Y., Bastos, D.H.M., Sampaio, G.R., Torres, E.A.F.S. (2009). Garlic (Allium sativum L.) and ready-to-eat garlic products: In vitro antioxidant activity. Food Chemistry, 115(1), 371-374. https://doi.org/10.1016/j.foodchem.2008.11.105

Sato, E., Kohno, M., Hamano, H., Niwano, Y. (2006). Increased anti-oxidative potency of garlic by spontaneous short-term fermentation. Plant Foods for Human Nutrition, 61, 157-160.

https://doi.org/10.1007/s11130-006-0017-5

Slinkard, K., Singleton, V.L. (1977). Total phenol analyses: automation and comparison with manual methods. American Journal of Enology and Viticulture, 28, 49-55.

Svendsen, C., Husøy, T., Glatt, H., Paulsen, J.E., Alexander, J. (2009). 5-Hydroxymethylfurfural and 5-sulfooxymethylfurfural increase adenoma and flat ACF number in the intestine of Min/p mice. Anticancer Research, 29(6), 1921-1926. 
Toledano Medina, M. A., Pérez-Aparicio, J., Moreno-Rojas, R., Merinas-Amo, T. (2016). Evolution of some physicochemical and antioxidant properties of black garlic whole bulbs and peeled cloves. Food Chemistry, 199, 135-139.

https://doi.org/10.1016/j.foodchem.2015.11.128

Tumors, C., Katsuki, T., Hirata, K., Ishikawa, H., Matsuura, N., Sumi, S., Itoh, H. (2006). Significance of garlic and its constituents in cancer and cardiovascular disease aged garlic extract has chemopreventative effects on. Journal of Nutrition, 136(12), 847S-851S.

https://doi.org/10.1093/jn/136.3.847S
Ulbricht, R.J., Northup, S.J., Thomas, J.A. (1984). A review of 5-hydroxymethylfurfural (HMF) in parenteral solutions. Fundamental and Applied Toxicology, 4, 843-853.

https://doi.org/10.1016/0272-0590(84)90106-4

Zhang, X., Li, N., Lu, X., Liu, P., Qiao, X. (2016). Effects of temperature on the quality of black garlic. Journal of the Science of Food and Agriculture, 96(7), 2366-2372. https://doi.org/10.1002/jsfa.7351 